\title{
Recent Status and Policy of Fine Dust in the Metropolitan Area of Korea
}

\author{
Ji Young Kim, Ji Ye Yoo, and Chan Jin Park
}

\begin{abstract}
Recently concerns about fine dust pollution are increasing. There was only attention to yellow dust and the concept of fine dust was not clear in few years ago. The worry about fine dust has become serious enough to distinguish sprinkling with fine dust even the naked eye in the sky.

The concentration of fine dust in Korea is higher than the World Health Organization recommendation level. In 2015, the annual averaged concentration of PM2.5 in Seoul is $23.1 \mu \mathrm{g} / \mathrm{m3}$ and the daily averaged maximum value is $70 \mu \mathrm{g} / \mathrm{m} 3$, far exceeding the recommended standards of the World Health Organization.

We have target of $30 \%$ reduction of fine dust emission in 2022 when compared with the special measures for fine dust management in 2016 as a comprehensive dust management policy. There is a big difference between the power generation sector and the industrial sector in terms of domestic emission reduction policy measures. Plans for an eco-friendly cooperative system and network for the protection of sensitive groups are being proceeded.

We investigated the characteristics of comprehensive measures for fine dust management and measures to reduce fine dust in the metropolitan area. And we also suggested improvement plans for the particulate management in Korea.
\end{abstract}

Index Terms-Fine dust $\left(\mathbf{P M}_{10}\right)$, ultrafine dust $\left(\mathbf{P M}_{2.5}\right)$.

\section{INTRODUCTION}

Recently, the fine dust pollution in urban regions are main issues in Korea. The weather forecast also required caution for the yellow dust coming in the spring of each year, and it was not long before started to give information on the concentration of fine dust. Until 4-5 years ago, the phenomena was invisible and did not feel serious. However, recently, the air quality has become worse and the fog about fine dust has become big enough to be easily judged by the naked eye.

In Fig. 1, the concentration of fine dust in Korea is not only higher than the World Health Organization (WHO) recommendation level, but also higher than that of major

Manuscript received March 15, 2018; revised April 27, 2018. This work was supported by Korea Ministry of Environment (MOE) as "Knowledge-based environmental service Human resource development Project".

Ji Young Kim is with the Department of Energy and Environment Engineering, Incheon National University, Republic of Korea (e-mail: jiyoungK@inu.ac.kr).

Ji Ye Yoo is with the Department of Climate International Cooperation, Incheon National University, Republic of Korea (e-mail: yoojiye@inu.ac.kr).

Chan Jin Park is with the Department of Energy and Env. Engineering and the Department of Climate International Cooperation, Incheon National University, Republic of Korea (corresponding author: Chan Jin Park; e-mail: cjpark@inu.ac.kr). developed countries such as Tokyo and London. According to the change of fine dust concentration in major cities in 2012-2014, the fine dust concentration in Seoul is higher than $40 \mu \mathrm{g} / \mathrm{m}^{3}$, while Tokyo and London are maintained about $20 \mu \mathrm{g} / \mathrm{m}^{3}$.

\section{Characteristic AND Status of Fine Dust}

\section{A. Major Sources of Emission of Fine Dust}

Fine dust is atmospheric pollutants including sulfurous acid gas, nitrogen oxides, lead, ozone, carbon monoxide, etc. It is fine dust particles with a diameter of $10 \mu \mathrm{m}$ or less which are generated in automobiles and factories and float in the air for a long period of time. When the particle size is $2.5 \mu \mathrm{m}$ or less, it is referred to as "PM2.5" and is called "ultrafine dust". In technical definition, it is called aerosol. Fine particles are also called suspended particles and particulate matter, and have slightly different meanings depending on their names. The aerodynamic diameter of the particulate matter is about $100 \mu \mathrm{m}$ to $10 \mathrm{~nm}$. If the particle size is larger than this, the residence time in the atmosphere is very short due to the sedimentation effect by gravity. [1]

The constituents of the fine dust may vary depending on the area where the fine dust is generated, the season, weather conditions, and the like. Generally, it consists of lumps (sulfate, nitrate, etc.) formed by the reaction of air pollutants in the air, carbon and soot generated in the process of burning fossil fuels such as coal and petroleum, and minerals such as earth dust. [1]

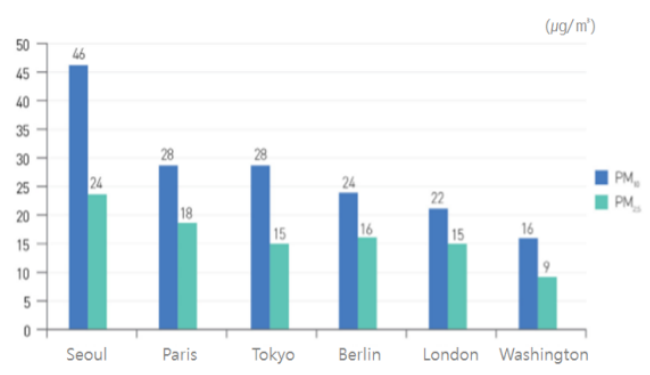

Fig. 1. Global ambient air pollution database [3].

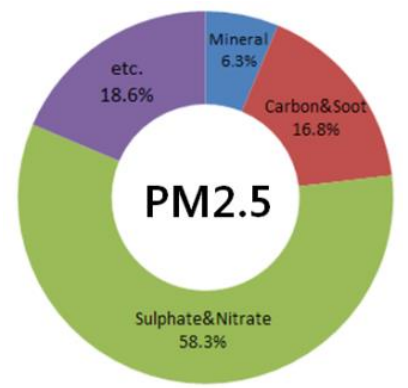

Fig. 2. Distribution ratio of PM 2.5 [1]. 
Fig. 2 shows the composition of fine dusts in the six major regions of the country, with the highest pollutant mass (sulfate, nitrate, etc.) being $58.3 \%$, carbon, soot $16.8 \%$ and minerals $6.3 \%$. [1]

\section{B. Causes of Fine Dust}

Fine dust generation sources are classified into natural and artificial ones. In case of emerging from a source such as a chimney to a solid fine dust (primary occurrence) and a source of gas, chemical substances react with other substances in the air to generate fine dust (Secondary occurrence). [1]

As can be seen from Fig. 3, PM2.5 is a precursor of nitrogen oxides, sulfur oxides, ammonia, volatile organic compounds, etc., which have been converted into nitrate, sulfate, ammonium, nonvolatile organic and organic carbon in the atmosphere. [1]

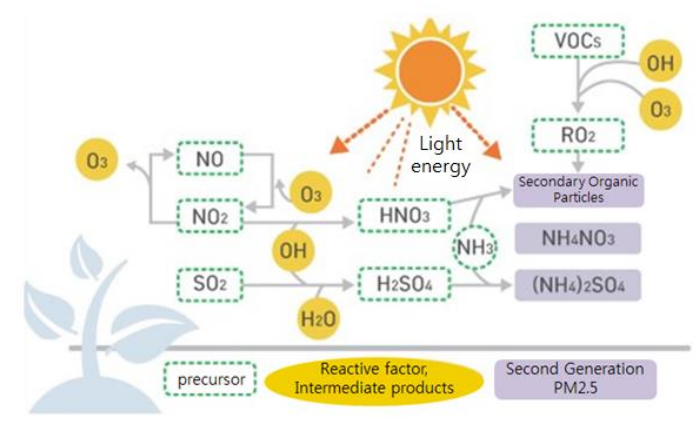

Fig. 3. Secondary process of PM2.5 [3].

In 2013, the total amount of primary dust emissions in the whole country was estimated to be about 122,000 tons of PM10 and about 77,000 tons of PM2.5. The emission source with the largest amount of fine dust emissions is the combustion process of the manufacturing industry, followed by a lot of mobile pollutants including automobiles. Most of the fine dust coming from the mobile pollutants is PM2.5, and its specific gravity reaches $92 \%$. Most of the fine dusts are emitted from vehicles in road vehicles and RV (SUV) vehicles. In case of non-road moving pollutants, fine dusts are generated in ships and construction equipment. [1]

Drifting-blowing dust refers to fine dust that is blown into the atmosphere without a constant outlet. It is estimated that the amount of fine dust generated due to drifting-blowing dust is very large, and the dust emission amount of the whole country is about 120,000 tons of PM10 and 1.8 million tons of PM 2.5. In the process of combustion of fossil fuels such as coal and petroleum, sulfur oxides are combined with water vapor and ammonia in the atmosphere, or nitrogen oxides from automobile exhaust gas are combined with atmospheric water vapor, ozone, ammonia, is generated, which is a secondary occurrence. Secondary fine dust is important because the secondary generation by chemical reaction accounts for more than $60 \%$ of total PM2.5 emissions in the metropolitan area. [1]

\section{FINE DUST STATUS OF KOREA}

Fig. 4 shows the space distribution of average yearly concentrations of fine dusts in the whole country. As a result, the concentrations in the northern and southern regions of
Gyeonggi-do, in the western part of Gangwon and in northern Chungbuk provinces are higher than those in other regions. In the case of PM2.5, there are many places where measurement stations are not installed, but it can be seen in the western part of Gangwon, northern part of Chungbuk area and southwestern part of Jeonbuk area are high. [2]
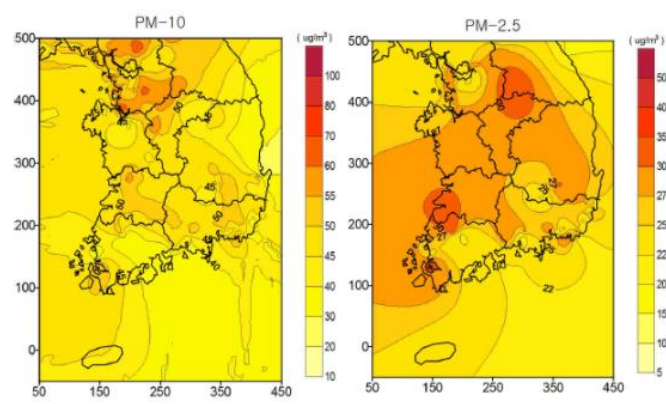

Fig. 4. Annual average concentration distribution [3].

The concentration of fine dust in Korea is not only higher than the World Health Organization (WHO) recommendation level, but also higher than that of major developed countries such as Tokyo, Paris, London and Washington. According to the PM2.5 map of major metropolitan cities announced by the World Health Organization (WHO), OECD countries in northern Europe and North America have good fine dust concentrations, while the average annual concentration on the Korean is 20-39 $\mu \mathrm{g} / \mathrm{m}^{3}$. In 2015, the annual concentration of PM2.5 in Seoul is $23.1 \mu \mathrm{g} / \mathrm{m}^{3}$ and the daily average maximum value is 70 $\mu \mathrm{g} / \mathrm{m}^{3}$, far exceeding the recommended standards of the World Health Organization (WHO). [2]

The concentration of fine dust in Korea is higher than that of major countries. In the 2016 Environmental Performance Index (EPI)' surveyed by Yale and Columbia University in the United States, Korea's air quality was ranked 173 among 180 countries, with the PM2.5 sector at 174, as in China. [2]

\section{COMPREHENSIVE MEASURES FOR FINE DUST MANAGEMENT IN KOREA}

As the needs for establishing special measures at the national level for solving the fine dust problem have arisen due to the frequent occurrence of high concentration fine dust from 2016, the "Special Measures for Fine dust Management" was announced on June 3, 2016. [5]

The basic directions of measures are

1) Scientific reduction of domestic sources

2) Simultaneously reduction of fine dust and $\mathrm{CO}_{2}$ and new industrial development

3) Environmental cooperation with neighboring countries

4) Forecast and alarm system innovation

5) All the people participate in the reduction of fine dust, but the burden of the people is minimized

Table I shows the target of $30 \%$ reduction of fine dust emission in 2022 when compared with the special measures for fine dust management in 2016 as a comprehensive dust collecting measure. There is a big difference between the power generation sector and the industrial sector in terms of domestic emission reduction policy measures. It also plans to implement an eco-friendly cooperative bond system and to 
establish a network for the protection of sensitive groups. Furthermore, it is under consideration for the conclusion of external fine dust through the summit meeting.

TABLE I: COMPREHENSIVE MEASURES FOR FINE DUST MANAGEMENT IN KOREA [2]

\begin{tabular}{|c|c|}
\hline Sector & Details \\
\hline \multicolumn{2}{|c|}{ Reduction Goal : $30 \%$ reduction in domestic emissions in 2022} \\
\hline \multirow{3}{*}{ Power generator } & Review low coal-fired power plants \\
\hline & Old power plant shut down in spring \\
\hline & Renewable energy expands to $20 \%$ in 2030 \\
\hline \multirow{3}{*}{ Industry } & implementation of total dust system \\
\hline & Establishment of nitrogen oxide discharge fee \\
\hline & $\begin{array}{l}\text { Expansion of total management except metropolitan } \\
\text { area }\end{array}$ \\
\hline \multirow{5}{*}{ Transport } & $\begin{array}{l}\text { Expansion of eco-friendly cars Eco-friendly car } \\
\text { cooperation }\end{array}$ \\
\hline & Strengthening of vessels and port management \\
\hline & Expansion of low-emission construction machinery \\
\hline & $\begin{array}{l}\text { Strengthening of motorcycle management and } \\
\text { supply electric motorcycle }\end{array}$ \\
\hline & Expansion of limit on operation area \\
\hline \multirow{7}{*}{ Sensitive layer } & Advancement of fine dust environment standard \\
\hline & $\begin{array}{l}\text { Establishment of standards for fine dust in the } \\
\text { sensitive layer }\end{array}$ \\
\hline & $\begin{array}{l}\text { Expansion of measurement networks near education } \\
\text { facilities }\end{array}$ \\
\hline & Establishment of Indoor Sports Facilities \\
\hline & $\begin{array}{l}\text { Conversion of children's commuting vehicles to } \\
\text { eco-friendly }\end{array}$ \\
\hline & Care services for sensitive families \\
\hline & $\begin{array}{l}\text { Fine dust clean management zone designation } \\
\text { system }\end{array}$ \\
\hline \multirow{2}{*}{$\begin{array}{l}\text { International } \\
\text { Cooperation }\end{array}$} & Korea-China summit \\
\hline & $\begin{array}{l}\text { Give positive consideration on international } \\
\text { agreement of fine dust reduction }\end{array}$ \\
\hline
\end{tabular}

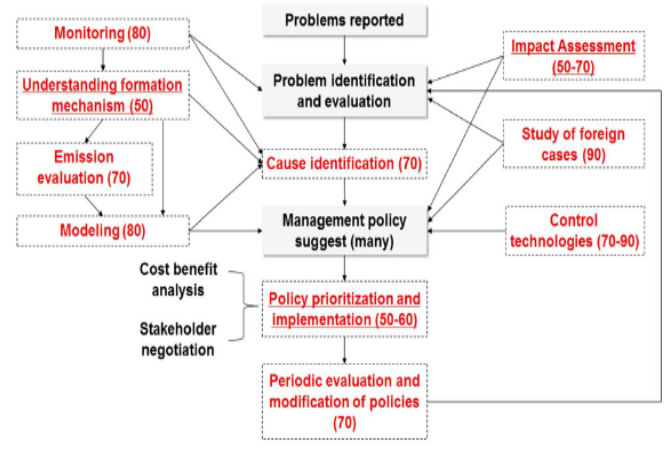

Fig. 5. The policy-making decisions diagram to reduce the ambient concentration of PM 2.5 [4].

Fig. 5 shows that the priority of the ultra fine dust control policy is to minimize the impact on the people and to prevent the people from being disturbed by ultrafine dust. To this end it is suggested that the goal of air management should be to reduce the concentration, especially the concentration reduction of the atmospheric environment reference material.

The Seoul Metropolitan Air and Environmental Authority changed the basic plan for improving the air environment in September 2017 to strengthen the fine dust countermeasures in accordance with the government's comprehensive measures for fine dust management. [4], [6]

Compared with the government's comprehensive measures for the control of fine dust, the Air Environment Agency of the Metropolitan Area assumed that it would be strengthened from $25 \mu \mathrm{g} / \mathrm{m}^{3}$ to $15 \mu \mathrm{g} / \mathrm{m}^{3}$ per year and $50 \mu \mathrm{g} / \mathrm{m}^{3}$ to $35 \mu \mathrm{g} / \mathrm{m}^{3}$ per 24 hours. [4], [6]

\section{A. Comprehensive Measures to Reduce Fine Dust in Seoul}

The Seoul Metropolitan Government announced the "Special Measures for Air Quality in Seoul" to reduce Seoul's annual average fine dust concentration to $20 \mu \mathrm{g} / \mathrm{m}^{3}$ by 2018 .

TABLE II: FIND DUST REDUCTION COMPREHENSIVE COUNTERMEASURES IN SEOUL [4]

\begin{tabular}{cl}
\hline \hline Sector & \multicolumn{1}{c}{ Action Plan } \\
\hline Transport & $\begin{array}{l}\text { Reduction of fine dust generated from diesel } \\
\text { vehicles } \\
\text { Eco-friendly cars such as electric cars } \\
\text { Strong traffic demand management }\end{array}$ \\
\hline $\begin{array}{c}\text { Living } \\
\text { surroundings }\end{array}$ & Daily scattered dust management \\
\hline $\begin{array}{c}\text { Find dust alarm } \\
\text { system }\end{array}$ & Complementing fine dust forecasting alarm system \\
\hline $\begin{array}{c}\text { Find dust } \\
\text { measurement } \\
\text { analysis }\end{array}$ & Scientific fine dust policy \\
\hline $\begin{array}{c}\text { Citizen health } \\
\text { Protection }\end{array}$ & Vulnerable class health care \\
\hline
\end{tabular}

TABLE III: FIND DUST REDUCTION COMPREHENSIVE COUNTERMEASURES IN INCHEON [4]

\begin{tabular}{|c|c|}
\hline Sector & Action Plan \\
\hline $\begin{array}{c}\text { Power } \\
\text { generation and } \\
\text { Industry }\end{array}$ & $\begin{array}{l}\text { Strengthen management of total amount of air } \\
\text { pollutant emission workplace } \\
\text { Reduce emissions of large-scale workplace } \\
\text { pollutants } \\
\text { Reduction of pollutant emissions from state-owned } \\
\text { enterprises such as ports and airports } \\
\text { Voluntary reduction of air pollutants } \\
\text { Special management of air pollutant discharge } \\
\text { business }\end{array}$ \\
\hline Transport & $\begin{array}{l}\text { Low-pollution measures for older cars } \\
\text { Limitation of automobile service } \\
\text { Reduction of non-road moving pollutant emissions } \\
\text { Special management of diesel automobile exhaust } \\
\text { gas } \\
\text { Supply eco-friendly car } \\
\text { Change to CNG bus }\end{array}$ \\
\hline $\begin{array}{c}\text { Living } \\
\text { surroundings }\end{array}$ & $\begin{array}{l}\text { Improvement of road dust reduction system } \\
\text { Management by scattered dust source }\end{array}$ \\
\hline $\begin{array}{c}\text { Find dust } \\
\text { measurement } \\
\text { analysis } \\
\end{array}$ & $\begin{array}{l}\text { Air pollution measurement analysis system } \\
\text { improvement }\end{array}$ \\
\hline $\begin{array}{l}\text { Find dust alarm } \\
\text { system }\end{array}$ & Enhanced alarm system operation and promotion \\
\hline etc. & $\begin{array}{l}\text { Expansion of green space to secure purification } \\
\text { capacity } \\
\text { Expansion of indoor air quality management } \\
\text { including multi-use facilities }\end{array}$ \\
\hline
\end{tabular}

Seoul's fine dust policy is divided into transport, living surrounding, fine dust alarm and etc. system as shown in Table II. Compared with the comprehensive measures for fine dust management, the emissions standard of coal power plants was strengthened as a means of domestic emission reduction policy, but the sensitive group did not yet reflect the protection measures.

\section{B. Comprehensive Measures to Reduce Fine Dust in Incheon}

Incheon city aims to reduce the concentration of PM10 below $40 \mu \mathrm{g} / \mathrm{m}^{3}$ and PM2.5 to below $24 \mu \mathrm{g} / \mathrm{m}^{3}$ by 2020 . As shown in Table III, the total amount management system for 
power generation and industrial sites was expanded, and low-emission measures of aging cars, eco-friendly cars, and $\mathrm{CNG}$ conversion of diesel buses were promoted in the transportation sector. In order to measure and analyze fine dust, the air pollution measurement and analysis system will be improved and a fine dust warning system will be operated.

\section{CONCLUSION}

Comprehensive measures for fine dust management in Korea are being proceeded in terms of reduction by regional sectors but it is not enough in actual effect of air quality improvement of urban regions.

Korea's fine dust alarm system does not reflect reduction measures for fine dust emission by unilateral forecasting such as weather forecast. On the other hand, major countries with excellent air quality management are working not only to build an alarm system but also to minimize the damage to fine dust by specifying measures to be taken at each stage. We also think that it is necessary to refine policy direction.

There is a problem that the network for measuring the concentration of fine dust in the atmosphere is locally concentrated, and the database construction and management for accumulating and analyzing the related data is insufficient. In the metropolitan area, the network is well established, but the number of networks in the Chungnam area, where the concentration of fine dust is increasing recently, is remarkably low. We think that measures to reduce fine dust should be specifically set up by strengthening administration and database construction management as well as installation of measurement site.

In order to solve the uneasiness of the people, it is essential not only to establish and implement policies based on science but also to publicize and comment on local governments, civic groups, and vulnerable groups. The cooperation of the government and citizens for reducing particulate emissions are indispensable for improving air quality in urban regions effectively.

\section{ACKNOWLEDGEMENT}

This work is financially supported by Korea Ministry of Environmnet (MOE) as "Knowledge-based environmental service Human resource development Project".

And, supported by Incheon Green Environment Center as "Develop Research Project".

\section{REFERENCES}

[1] The concept of fine dust(fine dust, what is it?), Ministry of Environment, 2016.

[2] Fine Dust Control Special Measures Status and Improvement Tasks, "Focused on transportation and power generation," National Assembly Budget Office, 2016.

[3] 2015 Annual Environmental Report, National Environmental Science Institute, 2016.

[4] Research and Policy Directions against Ambient Fine Particles, Young Pyo Kim, 2017

[5] Metropolitan Area Basic Plan, National Assembly Member Song Ok -ju Press Release, 2017.

[6] Comprehensive Measures for Fine Dust Control, Joint Ministry, 2017.

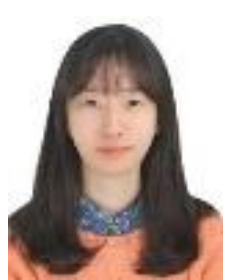

Ji Young Kim graduated from the Department of Environmental Engineering, Incheon National University. Her major fields of research are the air pollution control, greenhouse gas and odor management. She attends in the master's course of the Department of Environmental and Energy Engineering in Incheon National University.

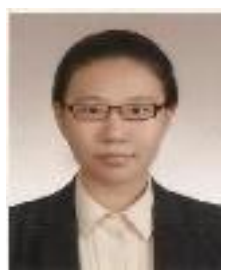

Ji YeYoo graduated from Incheon National University, and got the master degrees in same university. Her major fields of research are the air pollution control, greenhouse gas and odor management. She is now enrolled in a doctoral course at the Department of Climate International Cooperation, Incheon National University, Republic of Korea.

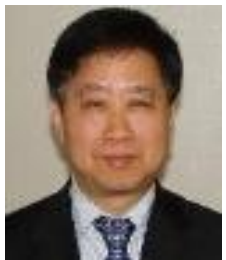

Chan Jin Park graduated from Korea University, and got Master and PhD degrees in same university. His major fields of research are the air pollution control, greenhouse gas technology and odor management technology. His interest is green growth policy. He is now full-professor in Urban Science College of Incheon National University. 